\title{
The aerosol radiative effects of uncontrolled combustion of domestic waste
}

\author{
John K. Kodros ${ }^{1}$, Rachel Cucinotta ${ }^{2}$, David A. Ridley ${ }^{3}$, Christine Wiedinmyer ${ }^{4}$, and Jeffrey R. Pierce ${ }^{1}$ \\ ${ }^{1}$ Department of Atmospheric Science, Colorado State University, Fort Collins, Colorado, USA \\ ${ }^{2}$ University of North Carolina at Charlotte, Charlotte, North Carolina, USA \\ ${ }^{3}$ Department of Civil \& Environmental Engineering, Massachusetts Institute of Technology, Cambridge, Massachusetts, USA \\ ${ }^{4}$ National Center for Atmospheric Research, Boulder, Colorado, USA
}

Correspondence to: John K. Kodros (jkodros@atmos.colostate.edu)

Received: 1 February 2016 - Published in Atmos. Chem. Phys. Discuss.: 25 February 2016

Revised: 16 May 2016 - Accepted: 17 May 2016 - Published: 3 June 2016

\begin{abstract}
Open, uncontrolled combustion of domestic waste is a potentially significant source of aerosol; however, this aerosol source is not generally included in many global emissions inventories. To provide a first estimate of the aerosol radiative impacts from domestic-waste combustion, we incorporate the Wiedinmyer et al. (2014) emissions inventory into GEOS-Chem-TOMAS, a global chemical-transport model with online aerosol microphysics. We find domestic-waste combustion increases global-mean black carbon and organic aerosol concentrations by 8 and $6 \%$, respectively, and by greater than $40 \%$ in some regions. Due to uncertainties regarding aerosol optical properties, we estimate the globally averaged aerosol direct radiative effect to range from -5 to $-20 \mathrm{~mW} \mathrm{~m}^{-2}$; however, this range increases from -40 to $+4 \mathrm{~mW} \mathrm{~m}^{-2}$ when we consider uncertainties in emission mass and size distribution. In some regions with significant waste combustion, such as India and China, the aerosol direct radiative effect may exceed $-0.4 \mathrm{~W} \mathrm{~m}^{-2}$. Similarly, we estimate a cloud-albedo aerosol indirect effect of $-13 \mathrm{~mW} \mathrm{~m}^{-2}$, with a range of -4 to $-49 \mathrm{~mW} \mathrm{~m}^{-2}$ due to emission uncertainties. In the regions with significant waste combustion, the cloud-albedo aerosol indirect effect may exceed $-0.4 \mathrm{~W} \mathrm{~m}^{-2}$.
\end{abstract}

\section{Introduction}

Open, uncontrolled combustion of domestic waste occurs on a global scale, potentially emitting significant amounts of black carbon (BC) and organic aerosol (OA); however, this source is not commonly considered in modeling studies estimating aerosol radiative impacts (Christian et al., 2010; Mohr et al., 2009; Wiedinmyer et al., 2014). Uncontrolled combustion of domestic waste refers to the intentional disposal of trash in an open fire either at home or at a dump (Wiedinmyer et al., 2014). This practice is common in developing countries in both rural and urban areas where municipal waste collection is insufficient; however, open combustion of domestic waste also occurs in rural developed countries (Christian et al., 2010; Wiedinmyer et al., 2014). The proximity of waste-combustion emissions to residences has created concerns for both air quality and climate. In a separate study, we estimate the global burden of mortalities due to chronic exposure of waste-combustion $\mathrm{PM}_{2.5}$ (Kodros et al., 2016). Here we provide a first estimate of the aerosol radiative impacts of domestic-waste combustion.

Carbonaceous aerosol from combustion sources can impact climate in several ways; the best understood of these being the direct radiative effect (DRE) and cloud-albedo aerosol indirect effect (AIE) (Boucher et al., 2013). The DRE refers to scattering and absorption of incoming solar radiation by aerosols (Charlson et al., 1992). The magnitude and relative amount of scattering and absorption is dependent on particle composition and size, as well as the manner of mixing of different species within a single particle (Bond et al., 2006, 2013). BC has a strong absorbing component, while OA is either considered as completely scattering or having some absorbing component in the shorter visible and ultraviolet wavelengths (i.e., brown carbon) (Andreae and Gelencsér, 2006; Hammer et al., 2016; Wang et al., 2014), al- 
though these optical properties of organic aerosol are an open area of research. Additionally, scattering and absorption efficiencies of carbonaceous particles depend on the ratio of particle diameter to wavelength of radiation. For solar radiation, atmospheric aerosol typically have peak efficiencies between diameters of $100 \mathrm{~nm}$ to $1 \mu \mathrm{m}$, though this will vary with composition (Seinfeld and Pandis, 2012). Finally, absorption tends to increase in an internally mixed population (all particles in a size range contain an identical mixture of all chemical species) compared to an externally mixed population (different chemical species exist in separate particles) (Chung and Seinfeld, 2005; Jacobson, 2001). In this study, we assume spherical particles, which is not realistic for fresh combustion aerosol. Details of particle shape may alter optical properties.

The cloud-albedo AIE refers to altering the reflectivity of clouds by changing the cloud droplet number concentration (CDNC) (Twomey, 1974). The ability for OA and BC cloud condensation nuclei $(\mathrm{CCN})$ to activate into cloud droplets is a strong function of particle size. In typical atmospheric conditions, $\mathrm{OA}$ and $\mathrm{BC}$ (when mixed with hydrophilic species) typically act as $\mathrm{CCN}$ when they have diameters larger than 40-100 nm (Petters and Kreidenweis, 2007). The number of particles in this size range is dependent on primary emissions as well as nucleation, condensation, and coagulation (Pierce and Adams, 2009). As these microphysical processes are often interconnected, the AIE response to an emission source may be nonlinear (e.g., additional primary emissions may reduce nucleation and condensation growth while increasing coagulation) (Bauer et al., 2010; Butt et al., 2016; D'Andrea et al., 2015). The AIE is also dependent on particle hygroscopicity (Petters and Kreidenweis, 2007). Particle hygroscopicity can be described with the hygroscopicity parameter, $\kappa$, which is the ratio of the number of moles of solute per dry volume to the moles of water per volume of pure water (Petters and Kreidenweis, 2007). While combustion aerosol tend to have lower hygroscopicity $(\kappa$ for $\mathrm{OA}=\sim 0.1$ and $\mathrm{BC}=0.0$ ), mixing with inorganic species, such as sulfate and sea salt, and chemical aging of the organics to morehygroscopic species allows for activation at smaller diameters.

Waste combustion is an often-overlooked emission source, especially in developing countries (Christian et al., 2010). Wiedinmyer et al. (2014) provided a new global inventory for the uncontrolled combustion of domestic waste, estimating global BC and OC emissions of 0.6 and $5.1 \mathrm{Tg}_{\text {year }}{ }^{-1}$, respectively. This estimate is an order of magnitude greater than earlier estimates of emissions from uncontrolled waste combustion in Bond et al. (2004) (which focused on combustion-aerosol emissions in general, not just from waste combustion). Amount of annual waste burned was the largest difference between the inventories, where Bond et al. (2004) estimated a total of $33 \mathrm{Tg}$ and Wiedinmyer et al. (2014) predicted $970 \mathrm{Tg}$. Further, Wiedinmyer et al. (2014) considered waste combustion in both rural and urban areas in develop- ing and rural areas in developed countries. Many global inventories, including Emissions Database for Global Atmospheric Research (EDGAR, Janssens-Maenhout et al., 2010), do not include estimates of uncontrolled waste-combustion emissions. In addition to carbonaceous emissions, Wiedinmyer et al. (2014) estimated $0.5 \mathrm{Tg}$ year $^{-1}$ of sulfur dioxide $\left(\mathrm{SO}_{2}\right)$ and $1.1 \mathrm{Tg}_{\text {year }}{ }^{-1}$ of ammonia $\left(\mathrm{NH}_{3}\right)$. These gasphase species may increase nucleation and condensation rates, thereby increasing particle number and mass concentration through secondary aerosol formation.

There are several uncertainties related to emissions in the Wiedinmyer et al. (2014) inventory. First, the reported uncertainty in the Akagi et al. (2011) emission factors for BC and $\mathrm{OC}$ are 42 and $93 \%$, respectively. This is in addition to uncertainties in the mass of waste generated (i.e., estimates of fuel use). Second, the Wiedinmyer et al. (2014) inventory does not include information on emission size distribution. The emitted particle size distribution varies with fuel type and flaming condition and goes through rapid aging in the first few hours after emission on spatial scales not resolved in global models (Janhäll et al., 2010; Sakamoto et al., 2016). Finally, this inventory does not include information on the optical properties of organic aerosol. Absorptive $\mathrm{OA}$ (or brown carbon, $\mathrm{BrC}$ ) has been observed in some wood and agricultural waste fuels, under certain flaming conditions (Chen and Bond, 2010; McMeeking et al., 2014; Saleh et al., 2013); however, we are not aware of studies determining these aerosol properties for domestic-waste combustion. In this paper, we explore uncertainties in total emission mass and size distribution (affecting both DRE and AIE) as well as optical properties (affecting just DRE).

To our knowledge, this is the first paper to quantify the global aerosol radiative impacts from uncontrolled combustion of domestic waste. In Sect. 2, we discuss the model set-up (Sect. 2.1), methods for model evaluation (Sect. 2.2), and calculation of radiative effects (Sects. 2.3-2.4). In Sect. 3, we show comparisons to ground observations of model simulations with and without waste-combustion emissions. In Sect. 4, we discuss changes in modeled aerosol mass (Sect. 4.1), size-resolved aerosol number concentration (Sect. 4.2), direct radiative effect (Sect. 4.3), and cloudalbedo aerosol indirect effect (Sect. 4.4). In Sect. 5, we share our conclusions.

\section{Methods}

\subsection{Model overview}

To calculate aerosol number, mass, and size distributions from domestic-waste combustion, we use the Goddard Earth Observing System global chemical-transport model (GEOSChem) version 10.01 coupled with TwO Moment Aerosol Sectional (TOMAS) microphysics scheme (Adams and Seinfeld, 2002). We use GEOS-Chem with 47 vertical layers 
Table 1. Description of simulations.

\begin{tabular}{lccl}
\hline Simulation & GMD* & $\begin{array}{c}\text { Mass scale } \\
\text { factor }\end{array}$ & Species \\
\hline BASE & $100 \mathrm{~nm}$ & 1.0 & primary and secondary \\
SIZE200 & $200 \mathrm{~nm}$ & 1.0 & primary and secondary \\
SIZE30 & $30 \mathrm{~nm}$ & 1.0 & primary and secondary \\
PRIMARY & $100 \mathrm{~nm}$ & 1.0 & primary BC and OA only \\
HIGHMASS & $100 \mathrm{~nm}$ & 2.0 & primary and secondary \\
LOWMASS & $100 \mathrm{~nm}$ & 0.5 & primary and secondary \\
WASTE_OFF & N/A & 0.0 & none \\
\hline
\end{tabular}

* GMD is geometric number-mean diameter.

and a $4^{\circ} \times 5^{\circ}$ horizontal resolution. This version of TOMAS uses 15 size sections ranging from $3 \mathrm{~nm}$ to $10 \mu \mathrm{m}$ with tracers for sulfate, sea salt, OA, BC, and dust (Lee and Adams, 2012; Y. H. Lee et al., 2013). GEOS-Chem is driven using reanalysis meteorology fields from GEOS5 (http://gmao.gsfc. nasa.gov). Since meteorology is prescribed, the addition of waste-combustion emissions does not feedback into weather patterns. All simulations are for the year 2010, with 1 month of model spinup that is not included in analysis.

We use a ternary nucleation scheme involving water, sulfuric acid, and ammonia following the parameterization of $\mathrm{Na}-$ pari et al. (2002), scaled with a global tuning factor of $10^{-5}$ (Jung et al., 2010; Westervelt et al., 2013). In addition, we use a binary nucleation scheme (sulfuric acid and water) when ammonia mixing ratios are less than 1 pptv (Vehkamäki et al., 2002). Secondary organic aerosol (SOA) sources include a biogenic monoterpene component of $19 \mathrm{Tg}_{\mathrm{year}}{ }^{-1}$ as well as an anthropogenically enhanced component of $100 \mathrm{Tg}_{\mathrm{gear}}{ }^{-1}$ (we do not know if the anthropogenically enhanced SOA is due to anthropogenic volatile organic compounds or an enhancement of biogenic SOA due to anthropogenic influences on chemistry) (D'Andrea et al., 2013; Spracklen et al., 2011). SOA is condensed irreversibly onto existing aerosol at the time of emission of the parent compounds using $10 \%$ of monoterpene emissions for the biogenic component and $0.2 \mathrm{Tg}$ SOA per Tg-CO for the anthropogenic component ( $\mathrm{CO}$ emissions are used as a proxy for the spatial and temporal distribution of anthropogenically enhanced SOA).

In all simulations we use the following emission inputs. We use fossil-fuel combustion anthropogenic emissions from the Emissions Database for Global Atmospheric Research (EDGAR; Janssens-Maenhout et al., 2010) version 4. EDGAR emissions are overwritten in the United States by the Environmental Protection Agency $2011 \mathrm{Na}-$ tional Emissions Inventory (NEI2011; http://www3.epa.gov/ $\mathrm{ttn} / \mathrm{chief} /$ ), in Canada by Criteria Air Contaminants (CAC; http://www.ec.gc.ca/inrp-npri/), in Mexico by Big Bend Regional Aerosol and Visibility Study (BRAVO; Kuhns et al., 2005), in Europe by the Cooperative Programme for Monitoring and Evaluation of the Long-Range Transmission of Air Pollutants in Europe (EMEP; Vestreng et al., 2009), and in Asia by the Streets inventory (Streets et al., 2003). Black (a) Organic aerosol

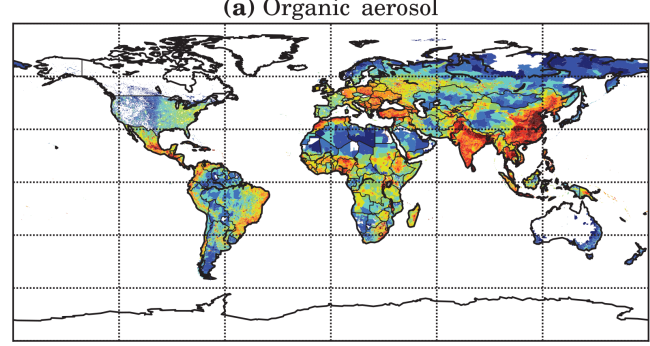

(b) Black carbon

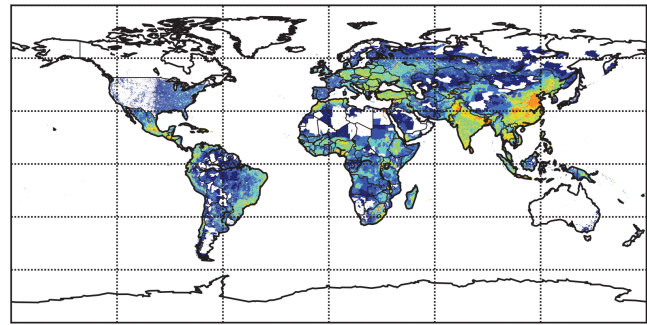

(c) $\mathrm{NH}_{3}$
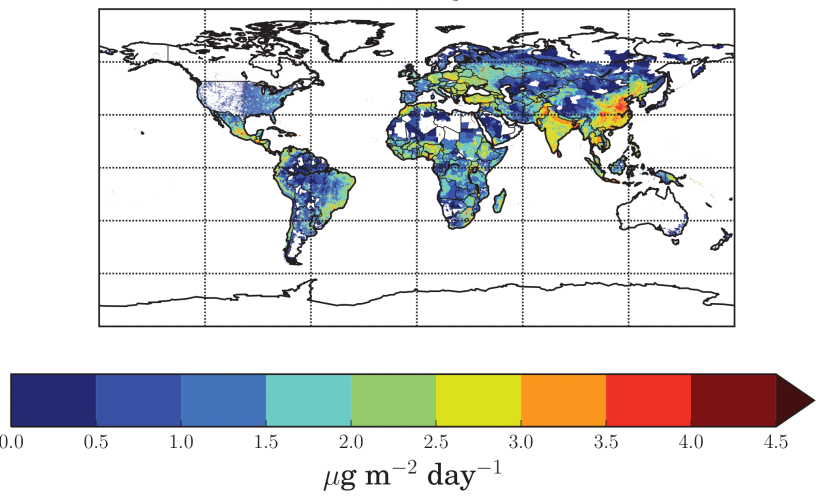

Figure 1. Emission fluxes from the open combustion of domestic waste for (a) organic aerosol, (b) black carbon, and (c) $\mathrm{NH}_{3}$ from Wiedinmyer et al. (2014).

and organic carbon (OC) emissions from biofuel and fossilfuel combustion are from Bond et al. (2007) and biomass burning from Global Fire Emissions Database version 3 (GFED3; van der Werf et al., 2010) with 3-hourly scale factors. Sea salt aerosol emissions follow the scheme of Jaeglé et al. (2011), while dust emissions are based on the DEAD scheme (Zender et al., 2003).

To estimate the impact of waste-combustion emissions, we include the Wiedinmyer et al. (2014) inventory to the above emissions set-up. Table 1 describes all simulations used in this study. Our BASE simulation uses total $\mathrm{BC}, \mathrm{OC}, \mathrm{SO}_{2}$, and $\mathrm{NH}_{3}$ mass as in Wiedinmyer et al. (2014). We emit $1 \%$ of $\mathrm{SO}_{2}$ as aerosol-phase sulfate $\left(\mathrm{SO}_{4}\right)$ and use a fixed $\mathrm{OA}$ to OC ratio of 1.8. We scale bulk $\mathrm{BC}$ and $\mathrm{OA}$ mass into size sections assuming a single lognormal mode with a geometric numbermean diameter (GMD) of $100 \mathrm{~nm}$ and a standard deviation of 2. We note that Wiedinmyer et al. (2014) do not include information on the emission size distribution, and this is a significant source of uncertainty (L. A. Lee et al., 2013). The spatial 
distribution of emissions is shown in Fig. 1 for OA, BC, and $\mathrm{NH}_{3}$. The emissions of $\mathrm{SO}_{2}$ show a similar spatial pattern but with a factor of 2 lower in magnitude than $\mathrm{NH}_{3}$. The regions with the largest particle emissions are eastern China, northern India, eastern Europe, and Mexico. To test the sensitivity of aerosol radiative effects to waste-combustion emission size distribution, we include two sensitivity simulations, SIZE200 and SIZE30. Here, we conserve total emission mass but increase the GMD from 100 to $200 \mathrm{~nm}$ and decrease the GMD from 100 to $30 \mathrm{~nm}$, respectively. These distributions are chosen to reflect the range of reported values from fresh and aged fossil fuel and biomass burning (Ban-Weiss et al., 2010; Carrico et al., 2010; Janhäll et al., 2004; Sakamoto et al., 2015). In Kodros et al. (2015), we also tested the sensitivity of aerosol radiative effects to uncertainty in the standard deviation of the emission size distribution and found the results are qualitatively similar to uncertainties in the GMD (a narrowing of the emission size distribution has a similar effect as to decreasing the value of the GMD, and visa versa), and so we do not include that here. In PRIMARY, we emit only aerosol-phase $\mathrm{BC}$ and $\mathrm{OA}$ waste combustion, and remove emissions of gas-phase $\mathrm{SO}_{2}$ and $\mathrm{NH}_{3}$, from this source. This simulation will test the contribution of nucleation and condensation from gas-phase species emitted from waste combustion. Finally, we test the sensitivity of aerosol effects to a factor of 2 uncertainty in total waste-combustion emission mass (HIGHMASS and LOWMASS). The factor of 2 uncertainty is similar to uncertainties listed in emission factors in Akagi et al. (2011). We compare these simulations to a control simulation with no waste-combustion emissions (WASTE_OFF).

\subsection{Aerosol optical depth (AOD) comparison}

We compare model aerosol optical depth with measurements made with the Aerosol Robotic Network (AERONET). AERONET is a network of ground-based remote sensing instruments aimed at providing global, long-term measurements of aerosol properties. AERONET uses a sun photometer to measure AOD at several wavelengths in $15 \mathrm{~min}$ intervals when the sun is not obscured by clouds (Holben et al., 1998).

To compare to AERONET measurements, we output GEOS-Chem-TOMAS size-resolved mass and number concentrations at $3 \mathrm{~h}$ intervals for the BASE and WASTE_OFF simulations. We calculate model AOD using refractive indices from the Global Aerosol Database (Koepke et al., 1997) and published Mie code (Bohren and Huffman, 1983). In this calculation, we only consider an external mixing-state assumption, though we note the extinction optical depth (what we are referring to as AOD) of an internal mixture is very similar (though the individual scattering and absorption optical depths are different). We average AERONET AOD into $3 \mathrm{~h}$ intervals and match measured time and locations with model AOD. We restrict observed AOD to contain greater than six measurements within each $3 \mathrm{~h}$ time period, thus removing intervals where measurements were limited due to clouds or instrument error. We also restrict our comparison to only include time periods when the observed AOD is greater than 0.01 to avoid detection-limit issues, as this is the uncertainty limit of AERONET measurements (Holben et al., 1998). We then compare the time average of the co-sampled sites that match these criteria.

\subsection{Direct radiative effect calculation}

We calculate the all-sky DRE using GEOS-Chem-TOMAS monthly averaged aerosol mass and number concentrations and refractive indices from GADS. We calculate AOD, single scatter albedo, and asymmetry parameter using Mie code published in Bohren and Huffman (1983). We use these aerosol optical properties and monthly mean albedo and cloud fraction from GEOS5 as inputs to the offline version of the rapid radiative transfer model for global climate models (RRTMG; Iacono et al., 2008), implemented in GEOS-Chem (Heald et al., 2014), that considers longwave and shortwave and treats clouds with the Monte Carlo independent column approximation (McICA; Pincus et al., 2003).

We estimate the DRE for six different optical assumptions: a core-shell morphology with and without absorptive $\mathrm{OA}$, an external mixture with a constant absorption enhancement factor of 1.5 (ext*1.5) with and without absorptive OA, a homogeneous internal mixture, and an external mixture. These optical assumptions are discussed in detail in Kodros et al. (2015) (see Table 1 in Kodros et al., 2015, and Table 3 in this paper) and are applied to all particles, regardless of emission source. In all cases, we assume the particles are spherical. Briefly, the homogeneous internal mixture assumes all particles in a size bin have the same composition and the refractive index of the particle is a volume-weighted average of the individual species. The core-shell mixture assumes black carbon forms a spherical core and the other hydrophilic species form a homogeneously mixed shell around the core. The external mixture assumes black carbon exists as a separate population from the other homogeneously mixed species. Finally, in ext* 1.5 we simply multiply the absorption predicted in the external mixture by a constant enhancement factor of 1.5. This is done in some models to estimate the enhanced absorption observed in core-shell mixtures (such as Wang et al., 2014). In the $\mathrm{BrC}$ calculations, we estimate absorptive OA (or brown carbon) using the modeled OA to $\mathrm{BC}$ ratio and the parameterization in Saleh et al. (2014). In all other calculations, we assume that $\mathrm{OA}$ is near-purely scattering throughout the visible spectrum.

We note several important limitations in our treatment of aerosol optics. First, mixing state may vary regionally and temporally, yet here we apply each mixing state globally and at all times. Second, it has been suggested that the optical properties of OA may change with photolysis, yet here our optical properties are held fixed (Lee et al., 2014; Zhao et al., 
2015). Therefore, these mixing states should be considered as ideal cases. Finally, we use monthly mean concentrations and properties as well as monthly mean cloud properties. Despite these limitations, we feel this method is sufficient for a first estimate of the DRE from waste-combustion emissions.

\subsection{Cloud-albedo aerosol indirect effect calculation}

We use monthly mean GEOS-Chem-TOMAS mass and number concentrations and the activation parameterization of Abdul-Razzak and Ghan (2002) to calculate CDNCs. We assume a constant updraft velocity of $0.5 \mathrm{~m} \mathrm{~s}^{-1}$. For the AIE, we assume aerosol species are mixed internally within each size bin and calculate $\kappa$, the hygroscopicity parameter, as a volume-weighted average of the individual species (Petters and Kreidenweis, 2007). As a control, we assume an effective cloud drop radii of $10 \mu \mathrm{m}$ and then perturb this value by taking the ratio of CDNC with and without waste-combustion emissions to the one-third power (as in Rap et al., 2013; Scott et al., 2014). To simulate the change in the top-of-theatmosphere radiative flux due to changes in effective cloud drop radii, we use RRTMG with monthly mean cloud fraction, temperature, pressure, and liquid water content from GEOS5. Again, we note that the use of monthly mean aerosol and meteorology fields is a limitation in this method, yet we feel it is sufficient for a first estimate.

\section{Model results}

\subsection{Comparison to observations}

Figure 2 shows comparisons of time-averaged model AOD with AERONET measured AOD at all available sites for the BASE (a-c) and WASTE_OFF (d-f) simulations at 380, 500, and $1020 \mathrm{~nm}$ wavelengths (one dot for each site). After we apply the criteria described in Sect. 2.2, we have 173 sites at $380 \mathrm{~nm}, 193$ sites at $500 \mathrm{~nm}$, and 211 sites at $1020 \mathrm{~nm}$. The model is generally capable of capturing the variability in measured AOD (in WASTE_OFF at $500 \mathrm{~nm}$ slope $=0.94$ and $\log$-mean bias $=-0.18$ ). Given the coarse spatial resolution of the model, the large variability is expected $\left(r^{2}=0.59\right)$, as more- and less-polluted areas may exist within the same model grid box ( $\sim 400 \mathrm{~km}$ length scale). Including wastecombustion emissions slightly improves the model comparison in all three metrics and at all wavelengths (with the exception of the slope at $1020 \mathrm{~nm}$ ). While these changes are not statistically significant, we note that GEOS-Chem-TOMAS has some skill at reproducing observed aerosol optical properties, and including this inventory does not degrade model comparison.

\subsection{Changes in mass concentrations from domestic-waste combustion}

Figure 3 shows the annual-mean percent change in boundarylayer $\mathrm{OA}, \mathrm{BC}, \mathrm{NH}_{3}$, and $\mathrm{PM}_{2.5}$ in the BASE-WASTE_OFF simulations, and global-mean $\mathrm{OA}$ and $\mathrm{BC}$ changes are in Table 2. Combustion of domestic waste under the BASE emission assumptions increases $\mathrm{BC}$ and $\mathrm{OA}$ concentrations in the global mean by 8.5 and $5.6 \%$, respectively. Regionally, domestic-waste combustion increases surface BC concentrations by $10-20 \%$ throughout much of Asia, northern Africa, and South and Central America. The largest increases in BC (greater than $40 \%$ ) occur in central Mexico (i.e., Mexico City), Turkey, northern Egypt (i.e., Cairo), Sri Lanka, and Papua New Guinea, as well as increases of $30-40 \%$ in Pakistan, Morocco, and Central America. Despite greater OA emissions, the relative change of OA from domestic-waste combustion is generally less than $\mathrm{BC}$ due to large OA sources from biofuel combustion and secondary organic aerosol in waste-combustion regions. Waste combustion does increase OA concentrations by more than $40 \%$ in Morocco, Turkey, Egypt, and the eastern portions of the Middle East. Increases in $\mathrm{BC}$ and $\mathrm{OA}$ lead to increases in surface $\mathrm{PM}_{2.5}$ concentrations of $1-5 \%$ over most land masses outside of North America and Australia and 5-10\% in source regions.

Figure 3 also shows the percent change in gas-phase $\mathrm{NH}_{3}$. Waste combustion contributes increases in $\mathrm{NH}_{3}$ of $1-10 \%$ in Mexico, Central and South America, and Africa. These are regions of significantly lower $\mathrm{NH}_{3}$ concentrations compared to Asia and Europe in our simulations, which have negligible relative changes to $\mathrm{NH}_{3}$. In our model, $\mathrm{NH}_{3}$ may contribute to particle nucleation and growth, which may alter particle size distributions (but have little effect on $\mathrm{PM}_{2.5}$ mass). These changes are discussed in the next section. Relative changes in $\mathrm{SO}_{4}$ mass generally follow the spatial pattern of OA; however, these changes are less than $1 \%$ and so are not shown.

Table 2 shows the global, annual-mean percent change in boundary-layer BC and OA mass for BASE and the sensitivity simulations compared to WASTE_OFF (thus isolating the contribution of domestic-waste combustion to $\mathrm{BC}$ and $\mathrm{OA})$. The largest changes to modeled $\mathrm{BC}$ and OA mass come when emission BC and OA mass is doubled (HIGHMASS) and halved (LOWMASS). In these simulations, the model response to changes in emission mass is close to linear. In simulations PRIMARY, SIZE30, and SIZE200, total BC and $\mathrm{OA}$ emission mass is held constant. The $\mathrm{BC}$ and $\mathrm{OA}$ mass distributions in SIZE30 and SIZE200 are shifted to smaller and larger sizes, respectively, which may lead to changes in deposition rates; however, these changes prove to be minor (Table 2). The global-mean relative change in $\mathrm{BC}$ and $\mathrm{OA}$ mass from domestic-waste combustion ranges from 4.23 to 16.9 and 2.80 to $11.2 \%$, respectively, given the factor of 4 uncertainty in emission mass tested here. 

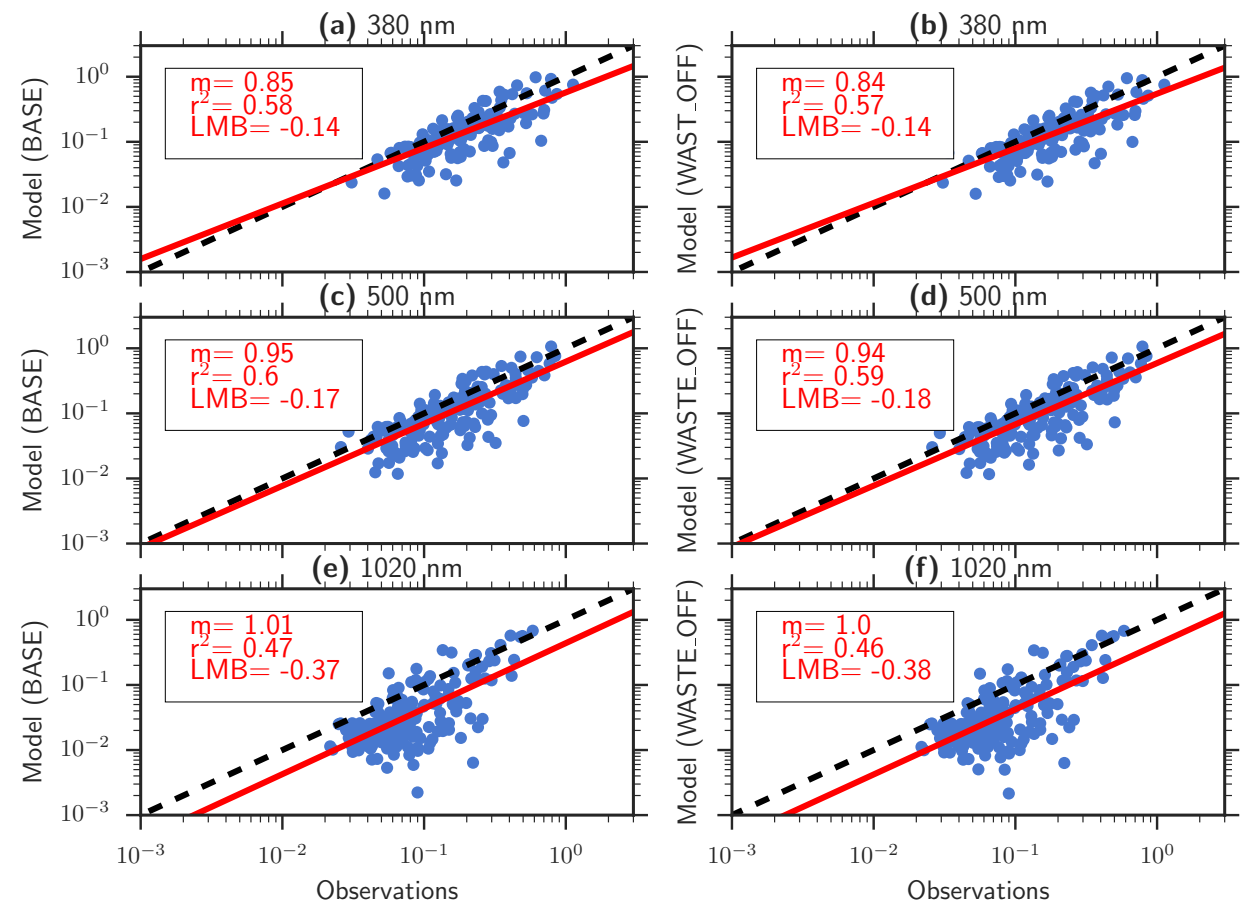

Figure 2. One-to-one plots of time-averaged AOD for BASE (a, $\mathbf{c}, \mathbf{e})$ and WASTE_OFF (b, d, f) compared to AERONET observations at $380 \mathrm{~nm}(\mathbf{a}, \mathbf{b}), 500 \mathrm{~nm}(\mathbf{c}, \mathbf{d})$, and $1020 \mathrm{~nm}(\mathbf{e}, \mathbf{f})$. The values in the box give the slope of the linear regression $(\mathrm{m})$, the correlation $\left(r^{2}\right)$, and the log-mean bias (LMB), while the black dashed line represents the $1: 1$ line and the red line is the result of the linear regression.

Table 2. Percent change in global, annual-mean N10, N40, N80, N150, BC mass, and OA mass from domestic-waste combustion (i.e., relative to WASTE_OFF simulation).

\begin{tabular}{lrrrrrr}
\hline Simulation & N10 $(\%)$ & N40 $(\%)$ & N80 $(\%)$ & N150 $(\%)$ & BC (\%) & OA $(\%)$ \\
\hline BASE & 0.86 & 0.90 & 1.04 & 1.16 & 8.46 & 5.60 \\
SIZE200 & 0.86 & 0.55 & 0.46 & 0.36 & 8.36 & 5.53 \\
SIZE30 & 4.02 & 5.43 & 5.42 & 4.40 & 8.07 & 5.14 \\
PRIMARY & -0.17 & 0.232 & 0.52 & 0.89 & 8.47 & 5.61 \\
HIGHMASS & 1.68 & 1.77 & 2.06 & 2.31 & 16.9 & 11.2 \\
LOWMASS & 0.44 & 0.45 & 0.53 & 0.59 & 4.23 & 2.80 \\
\hline
\end{tabular}

\subsection{Changes to size-resolved number concentrations}

Modeled percent changes to annual-mean size-resolved number concentrations for the BASE-WASTE_OFF comparison are shown in Fig. 4 and the global averages in Table 2. Here we consider the following size classes: all particles with a diameter greater than $10 \mathrm{~nm}(\mathrm{~N} 10), 40 \mathrm{~nm}(\mathrm{~N} 40), 80 \mathrm{~nm}(\mathrm{~N} 80)$, and $150 \mathrm{~nm}(\mathrm{~N} 150)$. N40, N80, and N150 are proxies for climate-relevant particles. In the global mean for our BASE assumptions, waste combustion leads to a larger increase in $\mathrm{N} 80(1.04 \%)$ and N150 (1.16\%) than in N10 (0.86\%) and $\mathrm{N} 40(0.90 \%)$. This is due to particle emissions represented as a single lognormal mode centered around $100 \mathrm{~nm}$ as well as a microphysical feedback (discussed below).

Regionally, the sign and magnitude of changes to particle number concentration vary with size class. Waste combustion tends to increase particle number concentration in each size class in Mexico, Central and South America, and the Pacific Islands. Conversely, waste combustion decreases N10 and N40 in much of Europe and Asia. This discrepancy is caused by a feedback in aerosol microphysics (discussed in detail in Westervelt et al., 2014; Pierce and Adams et al., 2009; Kodros et al., 2015). Briefly, emitted primary accumulationmode particles (in BASE this is centered around $100 \mathrm{~nm}$ ) increase particle surface area, thus increasing the sink for condensation vapors (e.g., $\mathrm{H}_{2} \mathrm{SO}_{4}, \mathrm{NH}_{3}$, organics). This increased condensation sink reduces nucleation rates, reduces growth rates, and increases coagulational scavenging of nucleation mode particles. This effect is predominant in Europe and Asia and for smaller size cutoffs (N10 and N40) with a significant contribution of nucleation mode particles (such that waste combustion emissions cannot compensate for the 
(a) OA

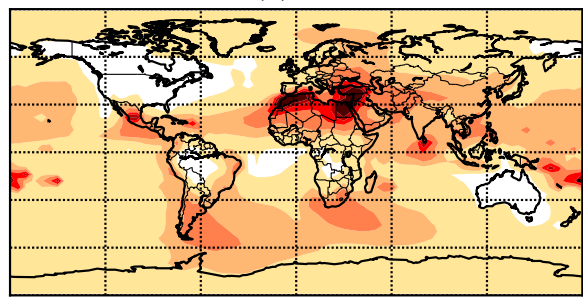

(c) $\mathrm{NH}_{3}$

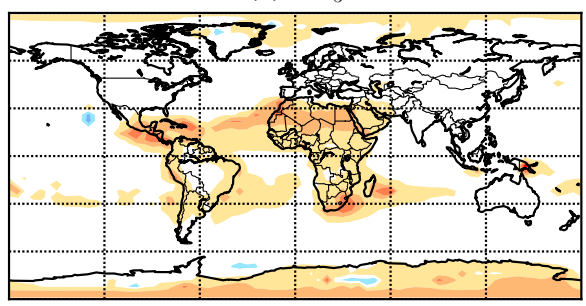

(b) $\mathrm{BC}$

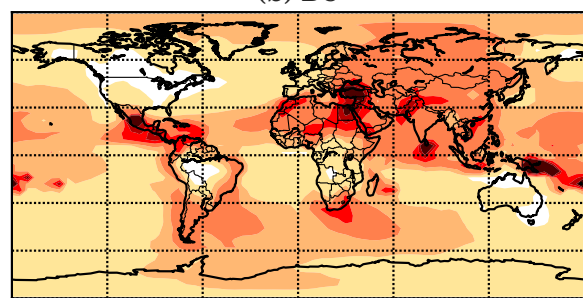

(d) $\mathrm{PM}_{2.5}$

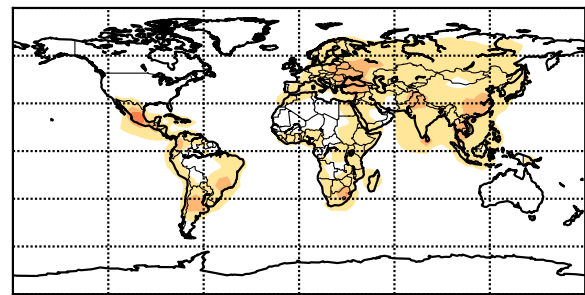

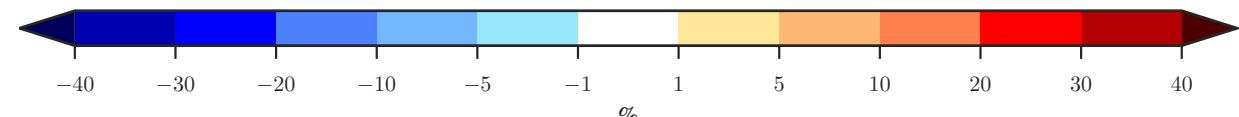

Figure 3. Percent changes in annually averaged boundary-layer (a) $\mathrm{OA}$, (b) $\mathrm{BC}$, (c) $\mathrm{NH}_{3}$, and (d) $\mathrm{PM}_{2.5}$ mass due to domestic-waste combustion (BASE-WASTE_OFF).

Table 3. Global-mean all-sky direct radiative effect and cloud-albedo aerosol indirect effect relative to the WASTE_OFF simulation for all sensitivity simulations and mixing-state assumptions.

\begin{tabular}{lrrrrrrr}
\hline \multirow{2}{*}{ Simulation } & \multicolumn{4}{c}{ Direct radiative effect $\left(\mathrm{mW} \mathrm{m}^{-2}\right)$} & \multicolumn{2}{c}{ AIE $\left(\mathrm{mW} \mathrm{m}^{-2}\right)$} \\
\cline { 2 - 7 } & Core-shell, BrC & Ext $^{*}$ 1.5, BrC & Homogenous & Core-shell & Ext*1.5 & External \\
\hline BASE & -5.0 & -8.7 & -11 & -13 & -17 & -20 & -13 \\
SIZE200 & +3.2 & -6.0 & -3.7 & -8.7 & -16 & -18 & -8.3 \\
SIZE30 & +4.1 & +3.7 & -1.5 & -1.6 & -2.3 & -5.8 & -49 \\
PRIMARY & -5.7 & -9.3 & -12 & -14 & -17 & -20 & -4.0 \\
HIGHMASS & -10 & -17 & -22 & -26 & -34 & -40 & -24 \\
LOWMASS & -2.5 & -4.3 & -5.6 & -6.5 & -8.7 & -10 & -6.7 \\
\hline
\end{tabular}

reduced nucleation and growth). The regions of Central and South America and Africa have lower concentrations of condensable vapor than Europe and Asia in WASTE_OFF, and so this feedback is less dominant. In addition, the Americas and Africa have a larger fractional increase in $\mathrm{NH}_{3}$ concentrations, which aid in nucleation and growth (Fig. 3).

Figure 5a shows the change in global-mean particle number distribution for each of the sensitivity simulations relative to WASTE_OFF. In the BASE-WASTE_OFF comparison, particle number concentration decreases for sizes less than $80 \mathrm{~nm}$ (due to the feedback described above) and increases for sizes greater than $80 \mathrm{~nm}$ (due to primary emissions) (see Table 2 for integrated values). The emission mass scale factor tends to scale the total waste combustion number distribution up or down, while maintaining the general shape of the distribution. The HIGHMASS simulation has a larger increase in accumulation-mode particles as well as a stronger suppression of nucleation/growth and thus a larger decrease in nucleation-mode particles relative to BASE. Meanwhile, LOWMASS scales in the opposite direction. In the PRIMARY simulation, we remove gas-phase $\mathrm{NH}_{3}$ and $\mathrm{SO}_{2}$ emissions from waste combustion, which contributes to particle nucleation and condensational growth. The removal of these condensable vapors results in a larger suppression of nucleation and growth relative to BASE, causing a larger decrease in sub- $80 \mathrm{~nm}$ particles as well as fewer particles in the $80-200 \mathrm{~nm}$ range. When only primary $\mathrm{BC}$ and OA from waste combustion are emitted, the global-mean N10 decreases $(-0.17 \%$, Table 2$)$. Nucleation and condensational growth is a less significant contributor to particles greater than $200 \mathrm{~nm}$, and so PRIMARY and BASE have the same distribution at these larger sizes.

Altering the GMD of the emissions size distribution leads to the largest changes in modeled distributions. In SIZE200, 
(a) $\mathrm{N} 10$

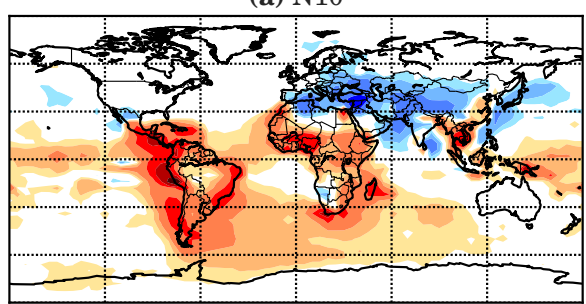

(c) $\mathrm{N} 80$

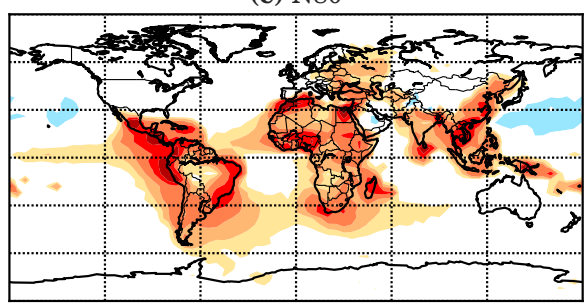

(b) $\mathrm{N} 40$

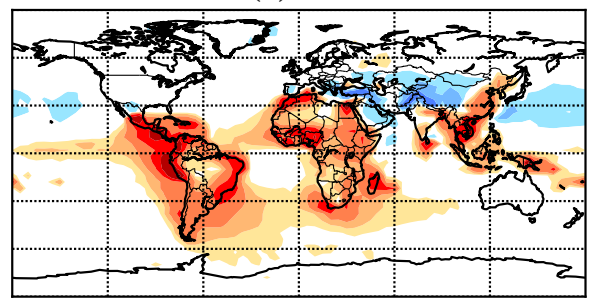

(d) N150

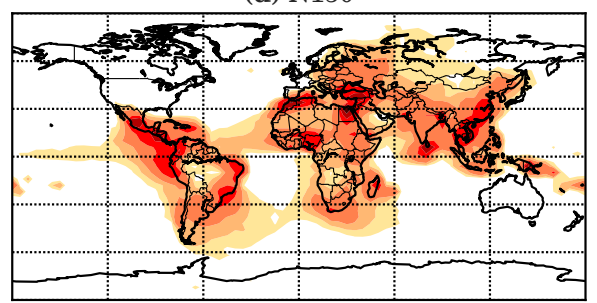

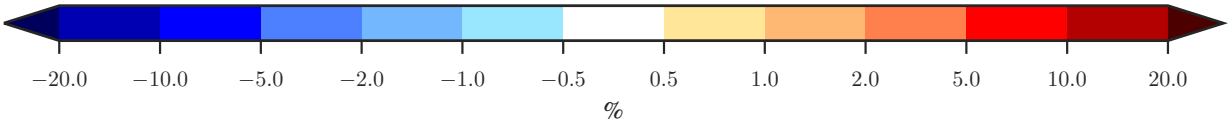

Figure 4. Annual-mean percent change in boundary-layer (a) N10, (b) N40, (c) N80, and (d) N150 for domestic-waste combustion (BASEWASTE_OFF).
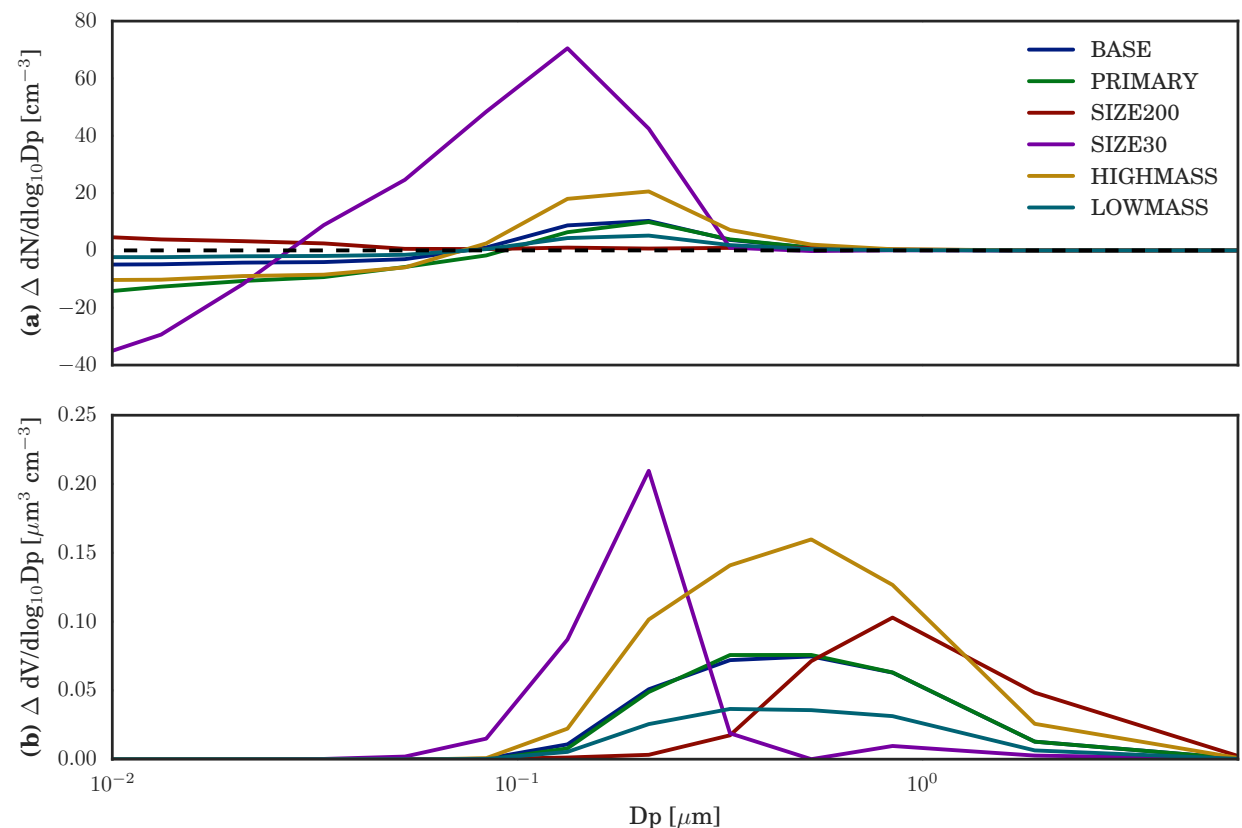

Figure 5. The change in global-mean (a) number distribution and (b) volume distribution for the different sensitivity studies relative to the WASTE-OFF simulation.

we increase emission GMD while keeping total mass constant. Assuming a constant density, this necessitates a smaller number flux of emitted particles (as larger particles have more mass). The reduced particle number concentration relative to BASE allows for nucleation through emitted $\mathrm{NH}_{3}$ and $\mathrm{SO}_{2}$ to increase the number of sub- $80 \mathrm{~nm}$ particles; however, increases in global-mean particle number concentration are less than $1 \%$ in all size classes (Table 2). Conversely, globalmean particle number concentration increases by greater than $4 \%$ in all size classes in the SIZE30 simulation. The increased particle number concentration does lead to a stronger suppression of nucleation; however, as emission GMD is 


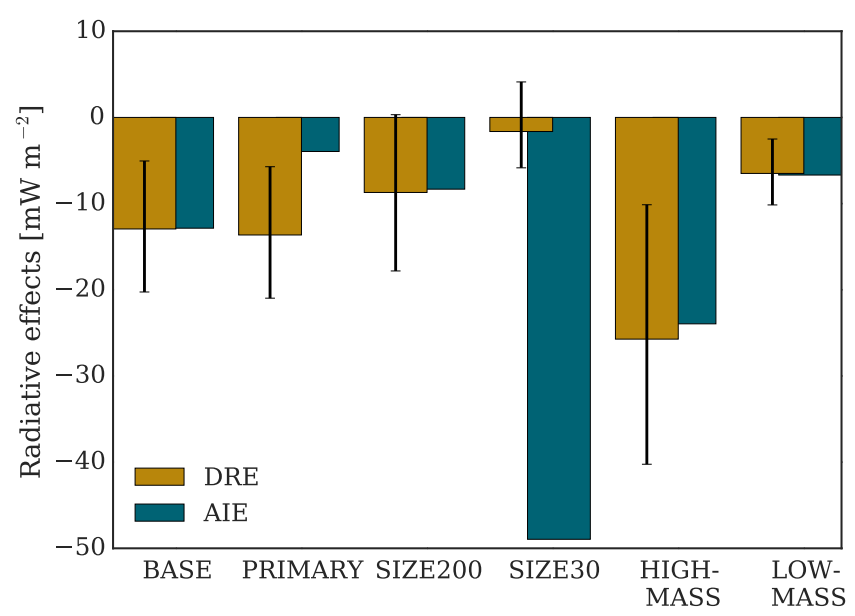

Figure 6. Global-mean all-sky direct radiative effect (DRE) and cloud-albedo aerosol indirect effect (AIE) for the baseline (BASE), aerosol-phase emissions only (PRIMARY), larger (SIZE200) and smaller (SIZE30) geometric mean diameter, and doubled (HIGHMASS) and halved (LOWMASS) emission mass relative to the WASTE_OFF simulation. The gold bars represent the DRE for the core-shell mixing state, while the error bars show the range due to the other optical assumptions.

now $30 \mathrm{~nm}$, particle number concentration changes become positive at $20 \mathrm{~nm}$ (compared to $80 \mathrm{~nm}$ for BASE). Across all simulations, our particle number concentration is most sensitive to decreasing the value of the GMD of the assumed size distribution. Thus, understanding near-source, sub-gridscale aging, which takes primary combustion particles from diameters around $30 \mathrm{~nm}$ to larger sizes (e.g., Sakamoto et al., 2016), is very important in determining the size-distribution effects of waste combustion. Across all sensitivity simulations, we find a range in the global-mean particle number concentration changes due to waste combustion of -0.2 to $4.0 \%$ for $\mathrm{N} 10,0.2$ to $1.8 \%$ in $\mathrm{N} 40,0.5$ to $5.4 \%$ in $\mathrm{N} 80$, and 0.4 to $4.4 \%$ in N150.

\subsection{Aerosol direct radiative effect}

Table 3 and Fig. 6 show the global-mean all-sky DRE from waste combustion for the six different mixing-state assumptions for the BASE-WASTE_OFF comparison as well as other sensitivity simulations. Under the BASE assumptions, the global-mean DRE is negative for all mixing states, ranging from -5 to $-20 \mathrm{~mW} \mathrm{~m}^{-2}$. Globally, the $\mathrm{OA}$ to $\mathrm{BC}$ ratio from waste-combustion emissions is around 14 to 1 , leading to increased scattering and a predominantly negative or cooling DRE. The relative emission mass of OA and $\mathrm{BC}$ is a source of uncertainty in Wiedinmyer et al. (2014). In Kodros et al. (2015), we found that the sign of the DRE is sensitive to the $\mathrm{OA}$ to $\mathrm{BC}$ ratio, where increasing the relative amount of $\mathrm{BC}$ leads to more positive (less negative) DRE. As in previous studies, the DRE becomes more positive when BC is assumed to be mixed internally (represented as core-shell, homogenous, and ext*1.5) as opposed to externally mixed and when $\mathrm{OA}$ is assumed to absorb as brown carbon.

Figure 7 shows maps of annual-mean all-sky DRE from waste combustion for all mixing states for BASEWASTE_OFF. Waste combustion causes a largely negative DRE in much of Asia, Eastern Europe, and the Americas. In regions with bright surfaces (high albedo), such as the $\mathrm{Sa}$ hara or Greenland ice sheet, the aerosol mixture has a highenough absorbing component to decrease planetary albedo and cause a positive or warming DRE. The largest-magnitude DRE from waste combustion occurs in eastern China (ranging from -0.4 to $-0.1 \mathrm{~W} \mathrm{~m}^{-2}$ ), as well as northern India and Eastern Europe $\left(-0.3\right.$ to $-0.05 \mathrm{~W} \mathrm{~m}^{-2}$ ).

Across all simulations and mixing-state combinations, the global-mean DRE from waste combustion ranges from -40 to $+4 \mathrm{~mW} \mathrm{~m}^{-2}$ (Table 3). In simulations HIGHMASS and LOWMASS, the factor-of-2 uncertainty in emission mass leads to approximately a factor-of- 2 scale in DRE. In PRIMARY, the removal of the emission gas-phase condensable vapors results in a reduction of sub- $200 \mathrm{~nm}$ particles, which does not greatly affect the volume distribution (Fig. 5b). As a result, the global-mean DRE in PRIMARY is similar to that in BASE. The slightly more negative DRE in the internal mixtures (core-shell and homogenous) may be a result of smaller shell diameters due to reduced condensation. Both SIZE200 and SIZE30 result in less negative DRE. In SIZE200, the mass distribution is moved to larger sizes, resulting in decreases in mass scattering and absorption efficiencies (the size distribution in the BASE simulation has nearly optimal mass scattering and absorption efficiencies). However, the fractional decrease in scattering efficiency is greater than that for absorption, resulting in a lower singlescattering albedo and an overall decrease in the magnitude of cooling. In SIZE30, the mass distribution is shifted to smaller sizes, which again lowers mass scattering and absorption efficiencies with a greater decrease in scattering relative to absorption. Again, this lowers the single-scattering albedo and decreases the magnitude of cooling.

\subsection{Cloud-albedo aerosol indirect effect}

Figure 8 shows the cloud-albedo AIE from domestic-waste combustion in the BASE-WASTE_OFF simulation. Wastecombustion emissions increase CDNC, and thus cloud reflectivity leading to a negative AIE in Central and South America, Africa, and the Pacific Islands. These are regions where the microphysical feedback suppressing nucleation and growth is less dominant, and waste combustion leads to increases in N40 (Fig. 4). Conversely, despite increases in aerosol mass from waste combustion in Asia and Europe, the AIE is 0 or slightly positive. This is caused by feedbacks in aerosol and cloud microphysics. The "suppression of nucleation and growth" feedback (described earlier) leads to decreases in N40 and thus CDNC. In addition, heavy anthro- 
(a) Core-shell, $\mathrm{BrC}$

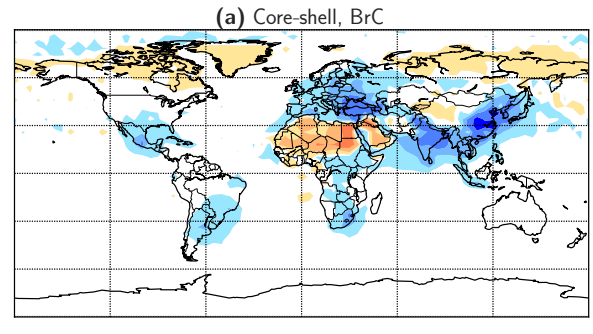

(c) Core-shell

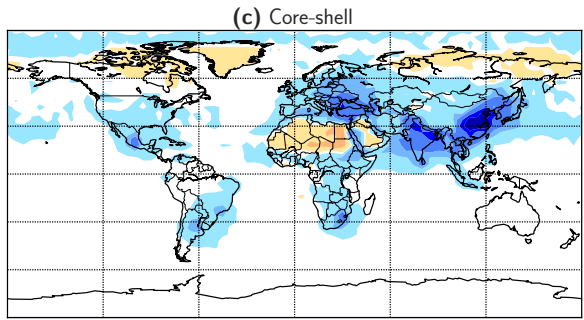

(e) Ext*1.5
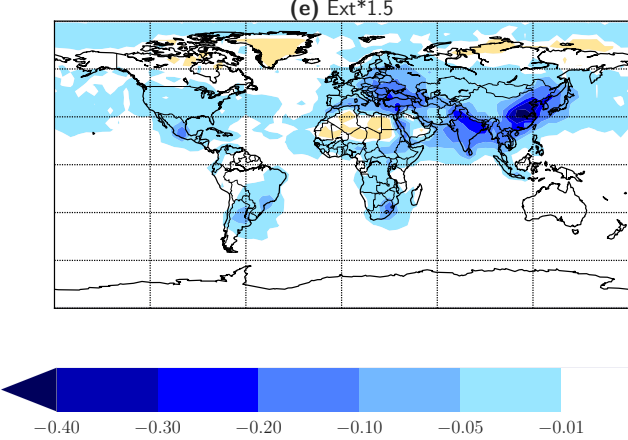

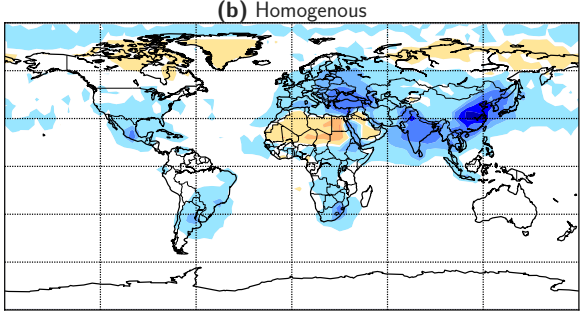

(d) $\mathrm{Ext}^{*} 1.5, \mathrm{BrC}$

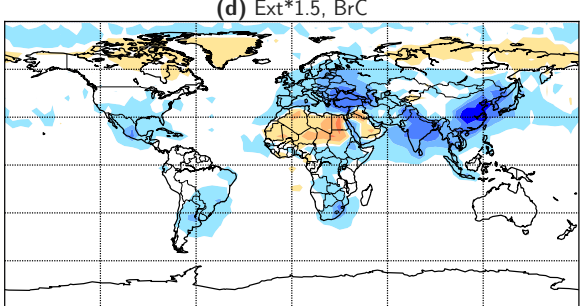

(f) External

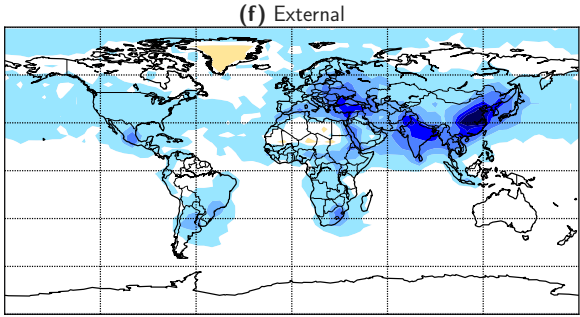

0.01

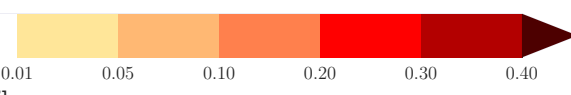

Figure 7. The all-sky direct radiative effect for domestic-waste combustion (BASE-WASTE_OFF) assuming a (a) core-shell with brown carbon, (b) homogenous internal, (c) core-shell, (d) external with brown carbon and an absorption enhancement factor of 1.5, (e) external with an absorption enhancement factor of 1.5 , and (f) external mixing state.
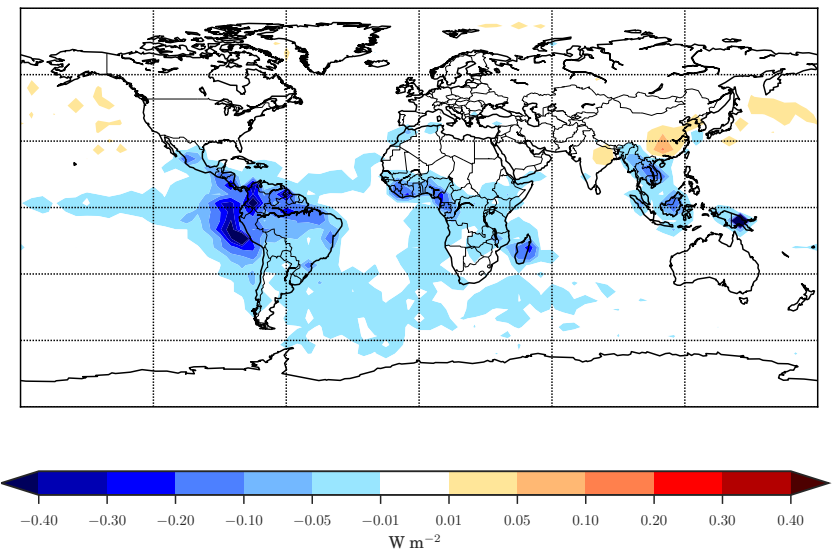

Figure 8. The cloud-albedo aerosol indirect effect difference between BASE-WASTE_OFF. pogenic pollution in India and China results in a strong competition for water vapor. Increases in N80 and N150 (Fig. 4) decrease the maximum supersaturation achieved in updrafts, which further limits droplet activation. As a result of the competing regional effects, the global-mean AIE for BASEWASTE_OFF is $-13 \mathrm{~mW} \mathrm{~m}^{-2}$ (Table 3 ).

The global, annual-mean AIE for all simulations is listed in Table 3 and plotted in Fig. 6. In the global mean, the AIE ranges from -4 to $-49 \mathrm{~mW} \mathrm{~m}^{-2}$ based on all emission uncertainties. In general, AIE is stronger in simulations with greater particle-number increases from waste combustion (SIZE30, HIGHMASS) and weakest in simulations with smaller particle-number increases (SIZE200, PRIMARY, LOWMASS). The largest-magnitude AIE occurs in the SIZE30 simulation $\left(-49 \mathrm{~mW} \mathrm{~m}^{-2}\right)$ due to the large increase in particle number concentration (Table 2 and Fig. 5). The lowest magnitude AIE occurs in the PRIMARY simulation, where condensable vapors from waste-combustion emissions are removed, leading to fewer particles in the 40 $200 \mathrm{~nm}$ size range relative to BASE (Fig. 5). This implies 
a non-trivial contribution of nucleation and growth to $\mathrm{CCN}$ concentrations from the $\mathrm{NH}_{3}$ and $\mathrm{SO}_{2}$ emissions from trash combustion.

\section{Conclusions}

In this paper, we use a global chemical-transport model to provide a first estimate of aerosol concentrations and radiative impacts from open, uncontrolled combustion of domestic waste. Using emissions from Wiedinmyer et al. (2014), we find increases in global-mean boundarylayer $\mathrm{BC}$ and $\mathrm{OA}$ mass of 8.5 and $5.6 \%$, with regional increases exceeding $40 \%$, relative to simulations without waste-combustion emissions. In our base simulations, we estimate that domestic-waste combustion emissions lead to a global-mean DRE ranging from -5 to $-20 \mathrm{~mW} \mathrm{~m}^{-2}$ (range due to optical assumptions) and an AIE of $-13 \mathrm{~mW} \mathrm{~m}^{-2}$. In areas where open waste combustion occurs, the resulting aerosol radiative impacts can range from -0.1 to $-0.4 \mathrm{~W} \mathrm{~m}^{-2}$. On a global scale, we find minor improvements of model AOD compared to observed AERONET AOD when including waste-combustion emissions.

We include several sensitivity simulations to explore uncertainties in waste-combustion emission size distribution, gas-phase species (leading to secondary aerosol), and emitted particulate mass. In the global, annual mean, we estimate a range in the DRE of +4 to $-40 \mathrm{~mW} \mathrm{~m}^{-2}$ and in the AIE of -4 to $-49 \mathrm{~mW} \mathrm{~m}^{-2}$. We find altering the wastecombustion emission size distribution while keeping total mass constant (SIZE200 and SIZE30) leads to substantial changes in the modeled size distribution, thus affecting the AIE $\left(-8\right.$ to $\left.-49 \mathrm{~mW} \mathrm{~m}^{-2}\right)$ and to a lesser extent the DRE $\left(+4\right.$ to $\left.-18 \mathrm{~mW} \mathrm{~m}^{-2}\right)$. In PRIMARY, we emit only primary BC and OA particles from waste combustion (and not particle-precursor gases). In this simulation, waste combustion leads to a stronger suppression of nucleation and growth, smaller increases in particle number concentration, and a lower magnitude AIE $\left(-4 \mathrm{~mW} \mathrm{~m}^{-2}\right)$. Thus, the particleprecursor gases emitted from waste combustion are important contributors to new-particle formation and growth, and they contribute to the negative AIE from waste-combustion emissions. We introduce a factor of 2 uncertainty in emission mass in HIGHMASS and LOWMASS. We find this leads to a near-linear increase in BC and OA mass and DRE $\left(-2.5\right.$ to $\left.-40 \mathrm{~mW} \mathrm{~m}^{-2}\right)$. Scaling emission mass up/down also increases/decreases emitted particle number concentration, leading to a range of AIE of -7 to $-24 \mathrm{~mW} \mathrm{~m}^{-2}$. There is little information on emission size distribution and optical properties from waste combustion. Better knowledge of these parameters along with continued validation of emission mass fluxes will reduce model uncertainty.

Our estimates for the aerosol radiative effects from waste combustion are relatively small compared to the total aerosol burden; however, they are of similar magnitude to recent es- timates of radiative impacts from biofuel combustion $(-0.06$ to $+0.08 \mathrm{~W} \mathrm{~m}^{-2}$ for the DRE and -0.05 to $+0.01 \mathrm{~W} \mathrm{~m}^{-2}$ for the AIE), another emission source associated with developing countries (Bond et al., 2013; Butt et al., 2016; Kodros et al., 2015; Lacey et al., 2015). Based on our estimates, it appears that the aerosol radiative effects from waste combustion likely have an overall cooling effect.

In a separate study (Kodros et al., 2016), we estimated that this waste-combustion aerosol leads to $284000(95 \%$ CI: $188000-404000)$ premature deaths globally each year. If waste-combustion aerosol were reduced to protect human health, this may also lead to a positive radiative forcing (warming tendency) due to a reduction of the wastecombustion-aerosol cooling. A reduction in waste combustion would also lead to a change in greenhouse gases, although these greenhouse-gas estimates are out of the scope of this paper due to the complex nature of greenhousegas emissions from waste decomposition and/or recycling. The greenhouse-gas changes due to choice of waste-removal method are an important topic to be studied in the future.

Acknowledgements. This research has been supported by a grant from the US Environmental Protection Agency's Science to Achieve Results (STAR) program through grant no. 83543801. Although the research described in the article has been funded by the US Environmental Protection Agency's STAR program, it has not been subjected to any EPA review and therefore does not necessarily reflect the views of the Agency, and no official endorsement should be inferred. David Ridley was funded through National Aeronautics and Space Administration grant NASA NN14AP38G

Edited by: A. Sorooshian

\section{References}

Abdul-Razzak, H. and Ghan, S. J.: A parameterization of aerosol activation 3. Sectional representation, J. Geophys. Res., 107, 4026, doi:10.1029/2001JD000483, 2002.

Adams, P. J. and Seinfeld, J. H.: Predicting global aerosol size distributions in general circulation models, J. Geophys. Res., 107, 4370, doi:10.1029/2001JD001010, 2002.

Akagi, S. K., Yokelson, R. J., Wiedinmyer, C., Alvarado, M. J., Reid, J. S., Karl, T., Crounse, J. D., and Wennberg, P. O.: Emission factors for open and domestic biomass burning for use in atmospheric models, Atmos. Chem. Phys., 11, 4039-4072, doi:10.5194/acp-11-4039-2011, 2011.

Andreae, M. O. and Gelencsér, A.: Black carbon or brown carbon? The nature of light-absorbing carbonaceous aerosols, Atmos. Chem. Phys., 6, 3131-3148, doi:10.5194/acp-6-3131-2006, 2006.

Ban-Weiss, G. A., Lunden, M. M., Kirchstetter, T. W., and Harley, R. A.: Size-resolved particle number and volume emission factors for on-road gasoline and diesel motor vehicles, J. Aerosol Sci., 41, 5-12, doi:10.1016/j.jaerosci.2009.08.001, 2010. 
Bauer, S. E., Menon, S., Koch, D., Bond, T. C., and Tsigaridis, K.: A global modeling study on carbonaceous aerosol microphysical characteristics and radiative effects, Atmos. Chem. Phys., 10, 7439-7456, doi:10.5194/acp-10-7439-2010, 2010.

Bohren, C. F. and Huffman, D. R.: Absorption and scattering of light by small particles, Wiley Interscience, New York, USA, 1983.

Bond, T. C., Streets, D. G., Yarber, K. F., Nelson, S. M., Woo, J. H., and Klimont, Z.: A technology-based global inventory of black and organic carbon emissions from combustion, J. Geophys. Res., 109, D14203, doi:10.1029/2003JD003697, 2004.

Bond, T. C., Habib, G., and Bergstrom, R. W.: Limitations in the enhancement of visible light absorption due to mixing state, J. Geophys. Res., 111, D20211, doi:10.1029/2006JD007315, 2006.

Bond, T. C., Bhardwaj, E., Dong, R., Jogani, R., Jung, S., Roden, C., Streets, D. G., and Trautmann, N. M.: Historical emissions of black and organic carbon aerosol from energy-related combustion, 1850-2000, Global Biogeochem. Cy., 21, GB2018, doi:10.1029/2006GB002840, 2007.

Bond, T. C., Doherty, S. J., Fahey, D. W., Forster, P. M., Berntsen, T., DeAngelo, B. J., Flanner, M. G., Ghan, S., Kärcher, B., Koch, D., Kinne, S., Kondo, Y., Quinn, P. K., Sarofim, M. C., Schultz, M. G., Schulz, M., Venkataraman, C., Zhang, H., Zhang, S., Bellouin, N., Guttikunda, S. K., Hopke, P. K., Jacobson, M. Z., Kaiser, J. W., Klimont, Z., Lohmann, U., Schwarz, J. P., Shindell, D., Storelvmo, T., Warren, S. G., and Zender, C. S.: Bounding the role of black carbon in the climate system: A scientific assessment, J. Geophys. Res. Atmos., 118, 5380-5552, doi:10.1002/jgrd.50171, 2013.

Boucher, O., Randall, D., Artaxo, P., Bretherton, C., Feingold, G., Forster, P., Kerminen, V.-M., Kondo, Y., Liao, H., Lohmann, U., Rasch, P., Satheesh, S. K., Sherwood, S., Stevens, B., and Zhang, X. Y.: Clouds and Aerosols. in: Climate Change 2013: The Physical Science Basis. Contribution of Working Group I to the Fifth Assessment Report of the Intergovernmental Panel on Climate Change, edited by: Stocker, T. F., Qin, D., Plattner, G.-K., Tignor, M., Allen, S. K., Boschung, J., Nauels, A., Xia, Y., Bex, V., and Midgley, P. M., Cambridge University Press, Cambridge, United Kingdom and New York, NY, USA, 2013.

Butt, E. W., Rap, A., Schmidt, A., Scott, C. E., Pringle, K. J., Reddington, C. L., Richards, N. A. D., Woodhouse, M. T., RamirezVillegas, J., Yang, H., Vakkari, V., Stone, E. A., Rupakheti, M., S. Praveen, P., G. van Zyl, P., P. Beukes, J., Josipovic, M., Mitchell, E. J. S., Sallu, S. M., Forster, P. M., and Spracklen, D. V.: The impact of residential combustion emissions on atmospheric aerosol, human health, and climate, Atmos. Chem. Phys., 16, 873-905, doi:10.5194/acp-16-873-2016, 2016.

Carrico, C. M., Petters, M. D., Kreidenweis, S. M., Sullivan, A. P., McMeeking, G. R., Levin, E. J. T., Engling, G., Malm, W. C., and Collett Jr., J. L.: Water uptake and chemical composition of fresh aerosols generated in open burning of biomass, Atmos. Chem. Phys., 10, 5165-5178, doi:10.5194/acp-10-5165-2010, 2010.

Charlson, R. J., Schwartz, S. E., Hales, J. M., Cess, R. D., Coakley, J. A., Hansen, J. E., and Hofmann, D. J.: Climate forcing by anthropogenic aerosols, Science, 255, 423-430, doi:10.1126/science.255.5043.423, 1992.

Chen, Y. and Bond, T. C.: Light absorption by organic carbon from wood combustion, Atmos. Chem. Phys., 10, 1773-1787, doi:10.5194/acp-10-1773-2010, 2010.
Christian, T. J., Yokelson, R. J., Cárdenas, B., Molina, L. T., Engling, G., and Hsu, S.-C.: Trace gas and particle emissions from domestic and industrial biofuel use and garbage burning in central Mexico, Atmos. Chem. Phys., 10, 565-584, doi:10.5194/acp10-565-2010, 2010.

Chung, S. H. and Seinfeld, J. H.: Climate response of direct radiative forcing of anthropogenic black carbon, J. Geophys. Res. 110, D11102, doi:10.1029/2004JD005441, 2005.

D'Andrea, S. D., Häkkinen, S. A. K., Westervelt, D. M., Kuang, C., Levin, E. J. T., Kanawade, V. P., Leaitch, W. R., Spracklen, D. V., Riipinen, I., and Pierce, J. R.: Understanding global secondary organic aerosol amount and size-resolved condensational behavior, Atmos. Chem. Phys., 13, 11519-11534, doi:10.5194/acp-1311519-2013, 2013.

D’Andrea, S. D., Acosta Navarro, J. C., Farina, S. C., Scott, C. E., Rap, A., Farmer, D. K., Spracklen, D. V., Riipinen, I., and Pierce, J. R.: Aerosol size distribution and radiative forcing response to anthropogenically driven historical changes in biogenic secondary organic aerosol formation, Atmos. Chem. Phys., 15, 2247-2268, doi:10.5194/acp-15-2247-2015, 2015.

Hammer, M. S., Martin, R. V., van Donkelaar, A., Buchard, V., Torres, O., Ridley, D. A., and Spurr, R. J. D.: Interpreting the ultraviolet aerosol index observed with the OMI satellite instrument to understand absorption by organic aerosols: implications for atmospheric oxidation and direct radiative effects, Atmos. Chem. Phys., 16, 2507-2523, doi:10.5194/acp-16-2507-2016, 2016.

Heald, C. L., Ridley, D. A., Kroll, J. H., Barrett, S. R. H., CadyPereira, K. E., Alvarado, M. J., and Holmes, C. D.: Contrasting the direct radiative effect and direct radiative forcing of aerosols, Atmos. Chem. Phys., 14, 5513-5527, doi:10.5194/acp-14-55132014, 2014.

Holben, B. N., Eck, T. F., Slutsker, I., Tanré, D., Buis, J. P., Setzer, A., Vermote, E., Reagan, J. A., Kaufman, Y. J., Nakajima, T., Lavenu, F., Jankowiak, I., and Smirnov, A.: AERONET - A Federated Instrument Network and Data Archive for Aerosol Characterization, Remote Sens. Environ., 66, 1-16, doi:10.1016/S0034-4257(98)00031-5, 1998.

Iacono, M. J., Delamere, J. S., Mlawer, E. J., Shephard, M. W., Clough, S. A., and Collins, W. D.: Radiative forcing by long-lived greenhouse gases: Calculations with the AER radiative transfer models, J. Geophys. Res., 113, D13103, doi:10.1029/2008JD009944, 2008.

Jacobson, M. Z.: Strong radiative heating due to the mixing state of black carbon in atmospheric aerosols, Nature, 409, 695-697, doi:10.1038/35055518, 2001.

Jaeglé, L., Quinn, P. K., Bates, T. S., Alexander, B., and Lin, J.-T.: Global distribution of sea salt aerosols: new constraints from in situ and remote sensing observations, Atmos. Chem. Phys., 11, 3137-3157, doi:10.5194/acp-11-3137-2011, 2011.

Janhäll, S., Jonsson, Å. M., Molnár, P., Svensson, A. E. and Hallquist, M.: Size resolved traffic emission factors of submicrometer particles, Atmos. Environ., 38, 4331-4340, doi:10.1016/j.atmosenv.2004.04.018, 2004.

Janhäll, S., Andreae, M. O., and Pöschl, U.: Biomass burning aerosol emissions from vegetation fires: particle number and mass emission factors and size distributions, Atmos. Chem. Phys., 10, 1427-1439, doi:10.5194/acp-10-1427-2010, 2010.

Janssens-Maenhout, A., Petrescu, A., Muntean, M., and Blujdea, V.: Verifying Greenhouse Gas Emissions: Methods to Support In- 
ternational Climate Agreements, The National Academies Press, Washington, DC, available at: http://www.nap.edu/openbook. php?record_id=12883 (last access: 17 March 2014), 2010.

Jung, J., Fountoukis, C., Adams, P. J., and Pandis, S. N.: Simulation of in situ ultrafine particle formation in the eastern United States using PMCAMx-UF, J. Geophys. Res., 115, D03203, doi:10.1029/2009JD012313, 2010.

Kodros, J. K., Scott, C. E., Farina, S. C., Lee, Y. H., L'Orange, C., Volckens, J., and Pierce, J. R.: Uncertainties in global aerosols and climate effects due to biofuel emissions, Atmos. Chem. Phys., 15, 8577-8596, doi:10.5194/acp-15-8577-2015, 2015.

Kodros, J. K., Wiedinmyer, C., Ford, B., Cucinotta, R., Gan, R., Magzamen, S., Pierce, J. R.: Global burden of mortalities due to chronic exposure to ambient PM2:5 from open combustion of domestic waste, in preparation, 2016.

Koepke, P., Hess, M., Schult, I., and Shettle, E. P.: Global Aerosol Data Set, Max Planck Inst. für Meteorol., Hamburg, Germany, 1997.

Kuhns, H., Knipping, E. M., and Vukovich, J. M.: Development of a United States-Mexico Emissions Inventory for the Big Bend Regional Aerosol and Visibility Observational (BRAVO) Study, J. Air Waste Manage. Assoc., 55, 677-692, doi:10.1080/10473289.2005.10464648, 2005.

Lacey, F. and Henze, D.: Global climate impacts of countrylevel primary carbonaceous aerosol from solid-fuel cookstove emissions, Environ. Res. Lett., 10, 114003, available at: http: //stacks.iop.org/1748-9326/10/i=11/a=114003 (last access: 26 May 2016), 2015.

Lee, H. J. J., Aiona, P. K., Laskin, A., Laskin, J., and Nizkorodov, S. A.: Effect of solar radiation on the optical properties and molecular composition of laboratory proxies of atmospheric brown carbon, Environ. Sci. Technol., 48, 10217-10226, doi:10.1021/es502515r, 2014.

Lee, Y. H. and Adams, P. J.: A Fast and Efficient Version of the TwO-Moment Aerosol Sectional (TOMAS) Global Aerosol Microphysics Model, Aerosol Sci. Technol., 46, 678-689, doi:10.1080/02786826.2011.643259, 2012.

Lee, L. A., Pringle, K. J., Reddington, C. L., Mann, G. W., Stier, P., Spracklen, D. V., Pierce, J. R., and Carslaw, K. S.: The magnitude and causes of uncertainty in global model simulations of cloud condensation nuclei, Atmos. Chem. Phys., 13, 8879-8914, doi:10.5194/acp-13-8879-2013, 2013.

Lee, Y. H., Pierce, J. R., and Adams, P. J.: Representation of nucleation mode microphysics in a global aerosol model with sectional microphysics, Geosci. Model Dev., 6, 1221-1232, doi:10.5194/gmd-6-1221-2013, 2013.

McMeeking, G. R., Fortner, E., Onasch, T. B., Taylor, J. W., Flynn, M., Coe, H., and Kreidenweis, S. M.: Impacts of nonrefractory material on light absorption by aerosols emitted from biomass burning, J. Geophys. Res. Atmos., 119, 12,272-12,286, doi:10.1002/2014JD021750, 2014.

Mohr, C., Huffman, J. A., Cubison, M. J., Aiken, A. C., Docherty, K. S., Kimmel, J. R., Ulbrich, I. M., Hannigan, M., and Jimenez, J. L.: Characterization of Primary Organic Aerosol Emissions from Meat Cooking, Trash Burning, and Motor Vehicles with High-Resolution Aerosol Mass Spectrometry and Comparison with Ambient and Chamber Observations, Environ. Sci. Technol., 43, 2443-2449, doi:10.1021/es8011518, 2009.
Napari, I., Kulmala, M., and Vehkamäki, H.: Ternary nucleation of inorganic acids, ammonia, and water, J. Chem. Phys., 117, 84188425, doi:10.1063/1.1511722, 2002.

Petters, M. D. and Kreidenweis, S. M.: A single parameter representation of hygroscopic growth and cloud condensation nucleus activity, Atmos. Chem. Phys., 7, 1961-1971, doi:10.5194/acp-71961-2007, 2007.

Pierce, J. R. and Adams, P. J.: Uncertainty in global CCN concentrations from uncertain aerosol nucleation and primary emission rates, Atmos. Chem. Phys., 9, 1339-1356, doi:10.5194/acp-91339-2009, 2009.

Pincus, R., Barker, H. W., and Morcrette, J. J.: A fast, flexible, approximate technique for computing radiative transfer in inhomogeneous cloud fields, J. Geophys. Res.-Atmos., 108, 4376, doi:10.1029/2002jd003322, 2003.

Rap, A., Scott, C. E., Spracklen, D. V., Bellouin, N., Forster, P. M., Carslaw, K. S., Schmidt, A., and Mann, G.: Natural aerosol direct and indirect radiative effects, Geophys. Res. Lett., 40, 3297 3301, doi:10.1002/grl.50441, 2013.

Sakamoto, K. M., Allan, J. D., Coe, H., Taylor, J. W., Duck, T. J., and Pierce, J. R.: Aged boreal biomass-burning aerosol size distributions from BORTAS 2011, Atmos. Chem. Phys., 15, 16331646, doi:10.5194/acp-15-1633-2015, 2015.

Sakamoto, K. M., Stevens, R. G., and Pierce, J. R.: The evolution of biomass-burning aerosol size distributions due to coagulation: dependence on fire and meteorological details and parameterization, Atmos. Chem. Phys. Discuss., doi:10.5194/acp-2016-9, in review, 2016.

Saleh, R., Hennigan, C. J., McMeeking, G. R., Chuang, W. K., Robinson, E. S., Coe, H., Donahue, N. M., and Robinson, A. L.: Absorptivity of brown carbon in fresh and photo-chemically aged biomass-burning emissions, Atmos. Chem. Phys., 13, 76837693, doi:10.5194/acp-13-7683-2013, 2013.

Saleh, R., Robinson, E. S., Tkacik, D. S., Ahern, A. T., Liu, S., Aiken, A. C., Sullivan, R. C., Presto, A. A., Dubey, M. K., Yokelson, R. J., Donahue, N. M., and Robinson, A. L.: Brownness of organics in aerosols from biomass burning linked to their black carbon content, Nat. Geosci., 7, 647-650, doi:10.1038/NGEO2220, 2014.

Scott, C. E., Rap, A., Spracklen, D. V., Forster, P. M., Carslaw, K. S., Mann, G. W., Pringle, K. J., Kivekäs, N., Kulmala, M., Lihavainen, H., and Tunved, P.: The direct and indirect radiative effects of biogenic secondary organic aerosol, Atmos. Chem. Phys., 14, 447-470, doi:10.5194/acp-14-447-2014, 2014.

Seinfeld, J. H. and Pandis, S. N.: Atmospheric chemistry and physics: from air pollution to climate change, John Wiley \& Sons., 2012.

Spracklen, D. V., Jimenez, J. L., Carslaw, K. S., Worsnop, D. R., Evans, M. J., Mann, G. W., Zhang, Q., Canagaratna, M. R., Allan, J., Coe, H., McFiggans, G., Rap, A., and Forster, P.: Aerosol mass spectrometer constraint on the global secondary organic aerosol budget, Atmos. Chem. Phys., 11, 12109-12136, doi:10.5194/acp-11-12109-2011, 2011.

Streets, D. G., Bond, T., Carmichael, G. R., Fernandes, S., Fu, Q., He, D., Klimont, Z., Nelson, S., Tsai, N. Y., Wang, M., Woo, J.-H., and Yarber, K. F.: An inventory of gaseous and primary aerosol emissions in Asia in the year 2000, J. Geophys. Res., 108, 8809, doi:10.1029/2002JD003093, 2003. 
Twomey, S.: Pollution and the planetary albedo, Atmos. Environ., 8, 1251-1256, 1974.

van der Werf, G. R., Randerson, J. T., Giglio, L., Collatz, G. J., Mu, M., Kasibhatla, P. S., Morton, D. C., DeFries, R. S., Jin, Y., and van Leeuwen, T. T.: Global fire emissions and the contribution of deforestation, savanna, forest, agricultural, and peat fires (19972009), Atmos. Chem. Phys., 10, 11707-11735, doi:10.5194/acp10-11707-2010, 2010.

Vehkamäki, H.: An improved parameterization for sulfuric acidwater nucleation rates for tropospheric and stratospheric conditions, J. Geophys. Res., 107, 4622, doi:10.1029/2002JD002184, 2002.

Vestreng, V., Ntziachristos, L., Semb, A., Reis, S., Isaksen, I. S. A., and Tarrasón, L.: Evolution of $\mathrm{NO}_{\mathrm{x}}$ emissions in Europe with focus on road transport control measures, Atmos. Chem. Phys., 9, 1503-1520, doi:10.5194/acp-9-1503-2009, 2009.

Wang, X., Heald, C. L., Ridley, D. A., Schwarz, J. P., Spackman, J. R., Perring, A. E., Coe, H., Liu, D., and Clarke, A. D.: Exploiting simultaneous observational constraints on mass and absorption to estimate the global direct radiative forcing of black carbon and brown carbon, Atmos. Chem. Phys., 14, 10989-11010, doi:10.5194/acp-14-10989-2014, 2014.
Westervelt, D. M., Pierce, J. R., Riipinen, I., Trivitayanurak, W., Hamed, A., Kulmala, M., Laaksonen, A., Decesari, S., and Adams, P. J.: Formation and growth of nucleated particles into cloud condensation nuclei: model-measurement comparison, Atmos. Chem. Phys., 13, 7645-7663, doi:10.5194/acp-13-76452013, 2013.

Westervelt, D. M., Pierce, J. R., and Adams, P. J.: Analysis of feedbacks between nucleation rate, survival probability and cloud condensation nuclei formation, Atmos. Chem. Phys., 14, 5577 5597, doi:10.5194/acp-14-5577-2014, 2014.

Wiedinmyer, C., Yokelson, R. J., and Gullett, B. K.: Global emissions of trace gases, particulate matter, and hazardous air pollutants from open burning of domestic waste., Environ. Sci. Technol., 48, 9523-9530, doi:10.1021/es502250z, 2014.

Zender, C. S.: Mineral Dust Entrainment and Deposition (DEAD) model: Description and 1990s dust climatology, J. Geophys. Res., 108, 4416, doi:10.1029/2002JD002775, 2003.

Zhao, R., Lee, A. K. Y., Huang, L., Li, X., Yang, F., and Abbatt, J. P. D.: Photochemical processing of aqueous atmospheric brown carbon, Atmos. Chem. Phys., 15, 6087-6100, doi:10.5194/acp15-6087-2015, 2015. 